\title{
ANALISIS PERUBAHAN NILAI TANAH DI AREA LERENG GUNUNG KELUD PASCA ERUPSI 2014 \\ (Studi Kasus: Kecamatan Ngancar, Kabupaten Kediri)
}

\author{
Udiana Wahyu Deviantari ${ }^{1}$, Yanto Budisusanto ${ }^{2}$, Mohammad Ibnu Aqil ${ }^{3}$ \\ 1,2,3 Institut Teknologi Sepuluh Nopember \\ Departemen Teknik Geomatika, FTSLK-ITS, Kampus ITS Sukolilo, Surabaya 60111, Indonesia \\ email: ${ }^{1}$ udiana@geodesy.its.ac.id
}

\begin{abstract}
Abstrak
Gunung Kelud merupakan salah satu gunung api aktif di Pulau Jawa. Gunung ini terakhir erupsi pada tahun 2014. Erupsi gunung ini mengakibatkan kerusakan pemukiman, kerusakan fasilitas umum, serta kerusakan lading-landang masyarakat sekitar Gunung Kelud yang menyebabkan gagal panen. Terjadinya perubahan kondisi fisik suatu wilayah dapat memicu perubahan nilai tanah di tersebut. Melihat status gunung yang aktif, keadaan seperti ini bisa dipastikan akan terulang di kemudian hari. Sehingga perlu adanya penelitan tentang perubahan nilai tanah di area lereng Gunung Kelud untuk mengetahui seberapa pengaruh erupsi gunung terhadap nilai tanah. Penelitian ini dilakukan dengan menumpang susunkan peta zona nilai tanah Kecamatan Ngancar Kabupaten Kediri tahun 2013, 2014, dan 2015 menggunakan perangkat lunak pengolah data spasial. Untuk mengetahui besar nilai tanah yang terjadi di lokasi penelitian. Data perubahan nilai tanah tersebut kemudian dilakukan uji korelasi dan regresi linear berganda dengan variabel bebas yang sudah ditentukan yaitu jarak zona terhadap pusat letusan, jarak zona dari CBD, dan jarak zona dari jalan kolektor. Tujuannya ialah mengetahui seberapa besar pengaruh erupsi Gunung Kelud dan variabel lainnya terhadap perubahan nilai tanah. Berdasarkan penelitian yang telah dilakukan, terjadi perubahan nilai tanah di Kecamatan Ngancar Kabupaten Kediri. Menurut hasil uji korelasi, erupsi Gunung Kelud 2014 tidak memiliki pengaruh yang besar terhadap perubahan nilai tanah. Dari hasil analisa regresi linear berganda yang dilakukan variabel yang dipilih hanya mampu menggambarkan 11,9\% pada tahun 2013-2014 dan 47,7\% pada tahun 2014-2015. Sehingga masih banyak faktor lain yang belum diketahui sebagai penyebab perubahan nilai tanah di Kecamatan Ngancar.
\end{abstract}

Kata Kunci-Nilai Tanah, Kecamatan Ngancar, Gunung Kelud

\section{PENDAHULUAN}

Nilai tanah (Land Value) didefinisikam sebagai pengukuran nilai tanah yang didasarkan atas kemampuan tanah secara ekonomis dalam hubungannya dengan strategi ekonimi dan produktivitasnya. Sedangkan nilai tanah itu sendiri merupakan perwujudan dari kemampuan tanah dalam hubungannya dengan penggunaan dan pemanfaatan tanah (Sujarto, 1986). Perubahan kondisi fisik dan lingkungan suatu wilayah bisa menjadi pemicu terjadinya perubahan seperti kerusakan lingkungan dan fasilitas umum. Salah satu penyenbab kondisi lingkungan berubah ialah bencana alam gunung meletus seperti yang terjadi pada Gunung Kelud tahun 2014.

Gunung Kelud merupakan salah satu gunung aktif yang ada di Pulau Jawa. Gunung ini telah mengalami 32 kali erupsi sejak tahun 1300 hingga tahun 2014 dan menyebabkan kerusakan 45.162 hektar lahan pertanian dan 15381 korban jiwa (Ramadhana, 2014). Erupsi 2014 menyebabkan kerusakan. baik dari segi lingkungan dan fisik maupun di bidang sosial ekonomi. Sarana dan prasarana mengalami kerusakan akibat tumpukan material hasil erupsi Gunung Kelud terlebih lagi pada daerah yang lokasinya bera di lereng gunung salah satunya ialah Kecamatan Ngancar Kabupaten Kediri.

Kecamatan Ngancar merupakan akses utama menuju ke area wisata Gunung Kelud Kabupaten Kediri dan merupakan daerah yang terkena dampak paling parah dari Erupsi Gunung Kelud (Wardani, 2014). Menurut data BPS tahun 2015 masyarakat yang hidup di kecamtan ini sebagian sebagai petani.Akan tetapi lahan di lereng Gunung Kelud mengalami kerusakan pasca terjadinya erupsi sehingga banyak petani yang mengalami gagal panen serta mendapatkan kerugian. Rusaknya lingkungan sekitar, sarana prasarana, 
dan beberapa bangunan mengalami kerusakan hingga perubahan sosial yang dialami oleh kecamatan tersebut dapat mempengaruhi nilai jual bidang tanah di kawasan itu. Dengan status Gunung Kelud yang masih aktif, kondisi seperti ini memiliki kemungkinan akan terulang lagi di kemudian hari.

Berdasarkan permasalahan tersebut diperlukan analisis perbandingan nila tanah sebelum dan sesudah erupsi di kawasan lereng Gunung Kelud. Diharapkan masyarakat mengetahui perubahan nilai tanah akibat suatu bencana dan penyebab perubahan nilai tanah di lereng Gunung Kelud pasca erupsi.

\section{METODE}

\section{Lokasi Penelitian}

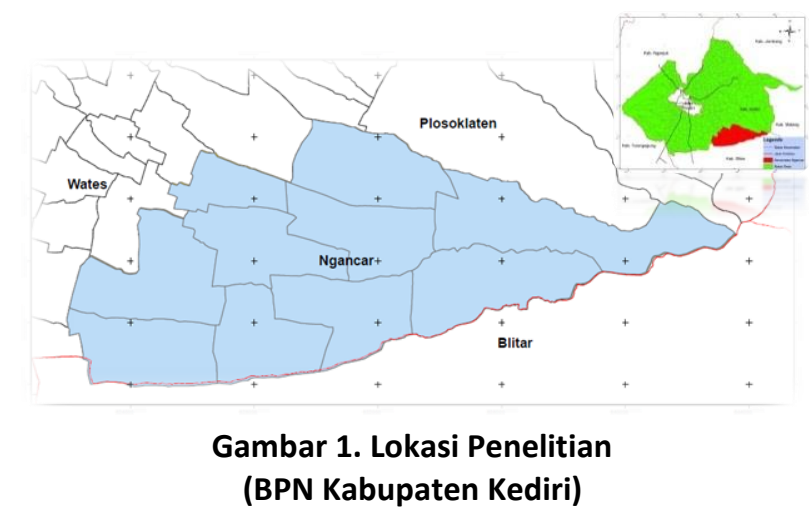

Lokasi dari penelitian yaitu Kecamatan Ngancar, Kabupaten Kediri, Jawa Timur, Indonesia. Luas wilayah $94,05 \mathrm{~km}^{2}$. Lokasi geografisnya terletak pada $112^{\circ} 6^{\prime} 45^{\prime \prime}$ sampai dengan $112^{\circ} 18^{\prime} 20^{\prime \prime}$ Bujur Timur dan $7^{0} 53^{\prime} 20^{\prime \prime}$ sampai dengan $7^{0} 58^{\prime} 45^{\prime \prime}$ Lintang Selatan.

Metode penelitian yang dilakukan pada penelitian ini yaitu menggunakan data spasial dan non spasial. Data spasial meliputi, koordinat titik-titik CBD, koordinat titik yang diperoleh dari survey lapangan, pusat letusan yang didapat dari Peta Rawan Bencana Gunung Kelud 2014 oleh BNPB. data Peta Zona Nilai Tanah (ZNT) 2013, 2014, dan 2015 yang diperoleh dari BPN Kabupaten Kediri, data jaringan jalan Kabupaten Kediri yang didapat dari website Ina-Geoportal, Peta Batas Administrasi Kabupaten Kediri yang diperoleh dari website Ina-Geoportal. Data non spasial adalah skuisioner sebagai pendukung penelitian yang dikumpulkan langsung di lapangan.

Overlay Peta ZNT 2013 dan ZNT 2014 untuk mengetahui perbedaan nilai tanah antara tahun 2013 sampai 2014 dari tiapa-tiap zona. Melakukan overlay Peta ZNT tahun 2014 dan 2015 untuk mengetahui perubahan nilai tanah yang terjadi antara tahun 2014 sampai 2015. Tujuannya ialah membandingkan kedua data tersebut untuk mengetahui seberapa besar perubahan nilai tanah di sekitar Lereng Gunung Kelud setelah terjadinya erupsi.

Memasukkan data perubahan nilai tanah hasil dari overlay ZNT 2013-2014 dan ZNT 2014-2015 ke dalam software pengolahan bersama dengan data spasial serta menyesuaikan sistem koordinat yang digunakan dengan data lain yang telah diplotting sebelumnya. Proses ini digunakan untuk menentukan besarnya nilai variabel yang dipakai. Variabel tersebut ialah jarak zona menuju ke pusat letusan, jarak zona ke CBD, dan jarak zona ke jalan kolektor.

Menentukan titik centroid atau pusat zona pada perangkat lunak pengolah data spasial. Titik ini akan digunakan sebagai titik pengukuran zona ke variabel yang sudah dipilih.

Pembuatan model regresi dari variabel yang telah ditentukan yaitu jarak dari jalan raya, jarak ke pusat letusan, dan jarak CBD. Model ini digunakan untuk mengetahui seberapa besar pengaruh yang diakibatkan oleh letusan Gunung Kelud terhadap perubahan nilai tanah di wilayah sekitarnya khususnya di Kecamatan Ngancar, Kabupaten Kediri.

Analisa perubahan nilai tanah dari model regresi yang telah dibuat serta digabungkan dengan data kuisioner untuk mengetahui seberapa besar perubahan dan pengaruhnya variabel yang dipilih terhadap nilai tanah di area Lereng Gunung Kelud. Pembuatan kuisioner tentang pengaruh erupsi Gunung Kelud 2014 terhadap perubahan nilai tanah di Kecamatan. Informasi yang dicari melalui kuisioner ini adalah harga pasar tanah sebelum terjadinya erupsi dan harga pasar tanah setelah terjadinya erupsi Gunung Kelud 2014 di Kecamatan Ngancar Kabupaten Kediri. Selain harga pasar tanah, informasi perilaku masyarakat yang hidup di area lereng gunung setelah terjadinya erupsi juga 
bisa menjadi perngaruh dalam perubahan nilai tanah di lokasi penelitian.

\section{HASIL DAN PEMBAHASAN}

\section{Perubahan Nilai Tanah}

Pada penelitian ini dilakukan perhitungan untuk mengetahui seberapa besar perubahan yang terjadi terhadap zona nilai tanah di Kecamatan Ngancar Kabupaten Kediri. Perhitungan ini dilakukan dengan menggunakan data zona nilai tanah (ZNT) milik Badan Pertanahan Nasional Kabupaten Kediri tahun 2013, 2014, dan 2015. Perubahan yang terjadi di area penelitian bisa dilihat peda gambar berikut:

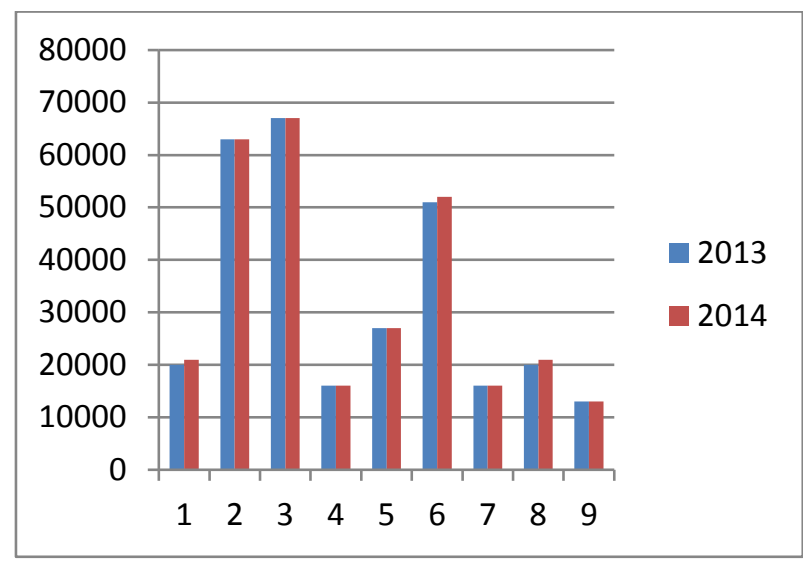

Gambar 2. Peningkatan Nilai Tanah Tahun 2013-2014

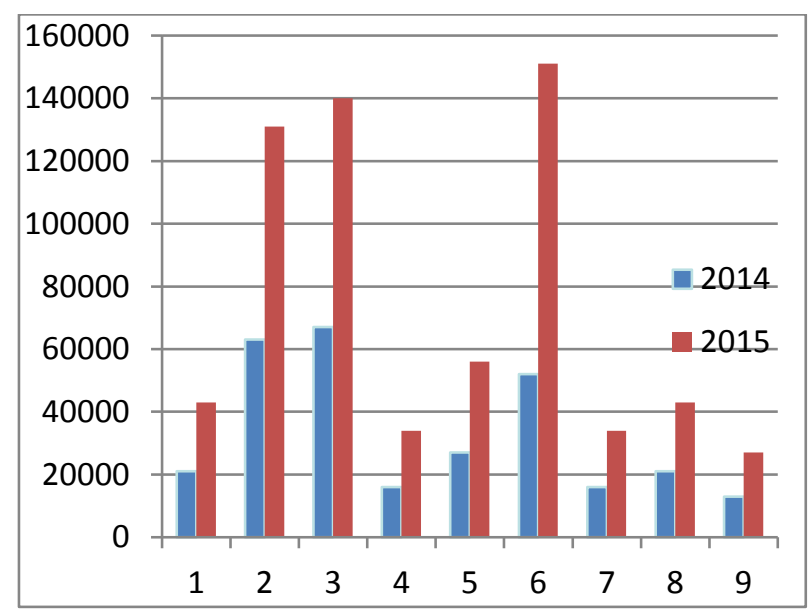

Gambar 3. Peningkatan Nilai Tanah Tahun 2014-2015

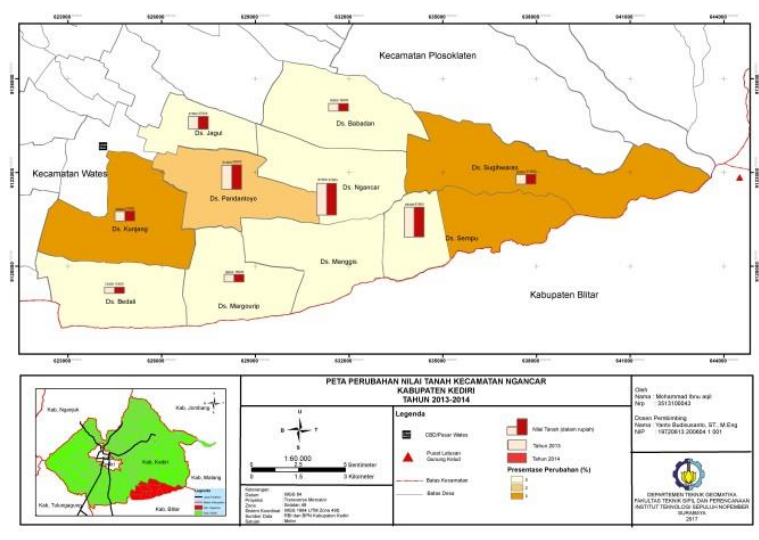

Gambar 4. Peta Perubahan Nilai Tanah Tahun 2013-2014

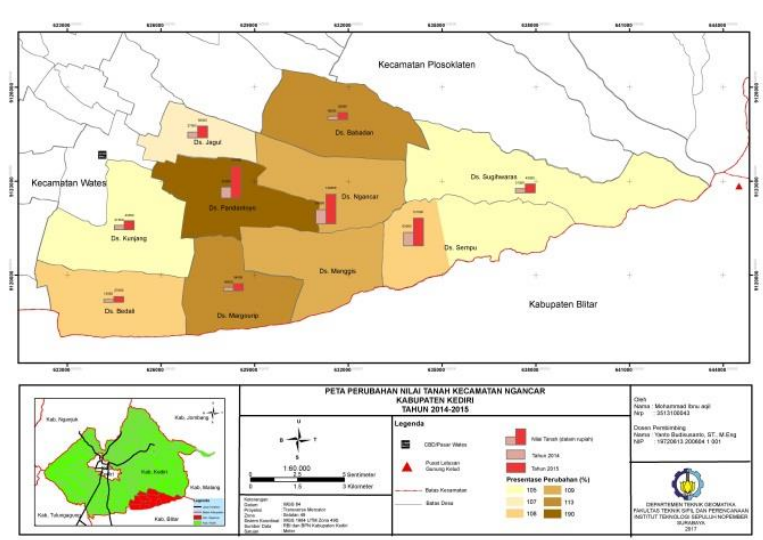

Gambar 5. Peta Perubahan Nilai Tanah Tahun 2014-2015

Terjadi perubahan nilai tanah di Kecamatan Ngancar Kabupaten Kediri setelah terjadinya erupsi Gunung Kelud. Dari 9 zona nilai tanah hanya terjadi peningkatan nilai tanah pada 3 zona sebesar $2 \%$ di Desa Pandantoyo, 5\% di desa Sugihwaras, dan 5\% di Desa Kunjang di tahun 2013-2014. Peningkatan sebesar $105 \%$ di Desa Sugihwaras dan Desa Kunjang, 107\% di Desa Jagul, 108\% di Desa Sempu dan Desa Bedali, 109\% di Desa Manggis dan Desa Ngancar, $113 \%$ di Desa Margourip dan Desa Babadan, dan $190 \%$ di Desa Pandantoyo pada tahun 2014-2015.

\section{Analisis Perubahan Nilai Tanah}

\section{- Uji Korelasi}

Uji korelasi berfungsi untuk mengetahui seberapa besar kekuatan yang terjadi antara dua variabel Analisis korelasi digunakan untuk mengetahui keeratan hubungan antara dua variabel dan untuk 
mengetahui arah hubungan yang terjadi. Perhitungan korelasi masing-masing variabel dihitung dengan menggunakan perangkat lunak pengolah data statistic (Walpole, 1995).

Hasil dari pengolahannya bisa dilihat dalam tabel berikut:

Tabel 1. Uji Korelasi Perubahan Nilai Tanah 2013-2014

\begin{tabular}{|c|c|}
\hline Variabel & $\mathbf{r}$ \\
\hline Pusat Letusan & -0.174 \\
\hline CBD & -0.064 \\
\hline Jalan Kolektor & 0.179 \\
\hline
\end{tabular}

Tabel 2. Uji korelasi Perubahan Nilai Tanah 2014-2015

\begin{tabular}{|c|c|}
\hline Variabel & $\mathbf{r}$ \\
\hline Pusat Letusan & 0.123 \\
\hline CBD & -0.341 \\
\hline Jalan Kolektor & -0.127 \\
\hline
\end{tabular}

\section{- Analisa Regresi Linear}

Analisa regresi merupakan analisis parametrik yang bertujuan untuk menentukan model matematika yang paling sesuai untuk pasangan data, sehingga dapat digunakan untuk membuat model dan meyelidiki atau menganalisis hubungan antara dua variabel atau lebih (Sarwono, 2010).

Model regresi linear perubahan nilai tanah tahun 2013-2014 yang didapat ialah sebagai berikut:

$$
Y=-186+5.9 X 1-0.053 X 2+6.1 X 3
$$

\section{Keterangan:}

$Y=$ Perubahan nilai tanah

$X 1=$ Jarak dari pusat letusan

$X 2=$ Jarak dari $\mathrm{CBD}$

$X 3=$ Jarak dari jalan kolektor

Tabel 3. R-Square Regresi Linear Perubahan Nilai Tanah 2013-2014

\begin{tabular}{|c|c|c|}
\hline $\mathbf{S}$ & $\mathbf{R}-\mathbf{S q}$ & $\mathbf{R}-\mathrm{Sq}(\mathbf{a d j})$ \\
\hline 2.58514 & $11.90 \%$ & $00.00 \%$ \\
\hline
\end{tabular}

$\mathrm{R}-\mathrm{Sq}\left(\mathrm{R}^{2}\right)$ digunakan untuk menunjukkan seberapa besar presentase (\%) variasi variabel bebas yang secara bersama-sama menjelaskan variabel terikat, sehingga dapat digunakan uji koefisien determinasi. Dari penelitian didapatkan nilai koefisien determinasi $\left(R^{2}\right)$ sebesar $11,90 \%$. Jadi berdasarkan model yang telah dibuat, perubahan nilai tanah hanya mampu dijelaskan oleh variabel bebas sebesar $11,90 \%$, dan sisanya dijelaskan oleh variabel lain yang tidak diteliti.

Adapun model regresi perubahan nilai tanah 20142015 dapat digambarkan dalam model berikut:

$$
\begin{aligned}
& Y=8297-262 \times 1-8.76 \times 2-260 \times 3 \\
& \text { Keterangan: } \\
& Y=\text { Perubahan Nilai Tanah } \\
& X 1=\text { Jarak dari pusat letusan } \\
& X 2=\text { Jarak dari CBD } \\
& X 3=\text { Jarak dari Jalan Kolektor }
\end{aligned}
$$

Tabel 4. $R$-Square Regresi Linear Perubahan Nilai Tanah 2014-2015

\begin{tabular}{|c|c|c|}
\hline $\mathbf{S}$ & R-Sq & R-Sq(adj) \\
\hline 25.1576 & $47.70 \%$ & $16.30 \%$ \\
\hline
\end{tabular}

hasil penelitian didapatkan nilai koefisien determinasi $\left(R^{2}\right)$ sebesar $47,70 \%$. Jadi model ini dijelaskan oleh variabel bebas sebesar $47,70 \%$, dan sisanya dijelaskan oleh variabel lain yang tidak diteliti.

\section{- Analisa Hasil Survei Kuisioner}

$50 \%$ responden yang diuji menyatakan bahwa erupsi Gunung Kelud tidak mempunyai pengaruh pada penetapan penjualan tanah di area lereng gunung. Mereka menjual tanah mereka sama dengan tahun-tahun sebelumnya, meskipun terjadi erupsi pada tahun 2014. Selain itu juga sikap masyarakat tetap ingin tinggal di wilayah tersebut, membuat harga tanah mereka akan tetap naik karena penawaran yang tinggi dan permintaan rendah.

Teori penawaran yang yang menjelaskan sifat hubungan antara jumlah barang yang ditawarkan dan harganya dikenal dengan hukum penawaran. Berdasarkan berdasarkan teori tersebut, Kenaikan nilai tanah di Kecamatan Ngancar Kabupaten Kediri akan terus mengalami peningkatan per tahunnya selama perilaku masyarakat yang tinggal di area tersebut tidak berubah. Sehingga sebuah erupsi gunung api tidak akan mempengaruhi perubahan nilai tanah. 


\section{KESIMPULAN}

Berdasarkan hasil dipenelitian ini, maka didapatkan beberapa kesimpulan akhir yaitu:

1. Terjadi perubahan nilai tanah di Kecamatan Ngancar Kabupaten Kediri setelah terjadinya erupsi Gunung Kelud. Dari hasil perhitungan menyatakan peningkatan nilai tanah sebesar 2\% di Desa Pandantoyo, 5\% di desa Sugihwaras, dan 5\% di Desa Kunjang pada tahun 2013-2014. Peningkatan sebesar 105\% di Desa Sugihwaras dan Desa Kunjang, 107\% di Desa Jagul, 108\% di Desa Sempu dan Desa Bedali, 109\% di Desa Manggis dan Desa Ngancar, 113\% di Desa Margourip dan Desa Babadan, dan 190\% di Desa Pandantoyo pada tahun 2014-2015.

2. Berdasarkan pengolahan data statistik, pusat letusan yang menjadi variabel bencana erupsi menunjukan hubungan yang rendah dengan besar nilai $-0,174$ dan $-0,123$ dari ketiga variabel yang digunakan dalam penelitian ini, variabel jarak terhadap titik CBD mempunyai korelasi paling besar terhadap perubahan nilai tanah yaitu sebesar - 0.341, yang menunjukkan korelasi terbalik.

3. Hasil pemodelan regresi linier berganda dan polinomial kuadratik menggunakan 3 variabel yang digunakan pada penelitian ini hanya menghasilkan koefisien determinasi yang kecil yaitu sebesar $11,90 \%$ dan $47,70 \%$ yang artinya 3 variabel yang digunakan bukan merupakan faktor utama yang berpengaruh terhadap perubahan nilai tanah.

\section{DAFTAR PUSTAKA}

Badan Pertanahan Nasional. 2015. Peta Zona Nilai Tanah Kabupaten Kediri. Kediri: Badan Pertanahan Nasional Kabupaten Kediri.

BPS Kabupaten Kediri. 2016. Kecamatan Ngancar Dalam Angka. Kediri: BPS Kabupaten Kediri

Ramadhana, A., dkk. 2014. Kajian Bentang Sumberdaya Lahan Gunungapi Kelud. dalam Bunga Rampai Penelitian Edisi Juli 2014.

Sarwono, Jonathan. 2013. 12 Jurus Ampuh SPSS untuk Riset Skripsi. Jakarta: Elexmedia Komputindo.

Sujarto, D. 1986. Perencanaan Kota Baru. Bandung: ITB.

Walpole, R.E. 1995. Pengantar Statistika Edisi ke 3. Jakarta : Gramedia.

Wardhani, dkk.2014. Dampak Erupsi Gunungapi Kelud Tahun 2014 pada Kondisi Sosial dan Ekonomi Masyarakat. Bunga Rampai Penelitian Edisi Juli 2014.

Yoeti, Oka A. 2008. Ekonomi pariwisata : introduksi, informasi, dan aplikasi. Jakarta: Kompas. 